\title{
Pembinaan Perencanaan Pemasaran Produk Bagi Anggota Pkk Asoka Dikota Batam
}

\author{
Raymond*1 \\ ${ }^{1}$ Universitas Putera Batam; address, Jalan R Soprapto tembesi Kota Batam \\ ${ }^{1}$ Program Studi Manajemen, Fakultas Ilmu Sosial dan Humaniora, Universitas Putera Batam \\ e-mail: *Raymond@puterabatam.ac.id
}

\begin{abstract}
Informasi Artikel
Abstract

Diterima Redaksi: 14 Januari 2019

The object to be fostered in this service is the Asoka PKK group

Revisi Akhir: -

Diterbitkan Online: 4 Februari 2019

located in Tanjung Piayu, a sustainable blue spur housing complex, 1 RW 05, Batam City. In community service this time will be carried out coaching in understanding and making business marketing planning, the method used in community service this time is the first

Kata Kunci

Team Lecturer to give lectures and presentation on business marketing planning theory, both Participants will be given guidance in making business marketing planning, third Participants will be given the opportunity to discuss the problems faced in making a business marketing plan. with the community service program this time contributing in the form of participants able to be skilled in planning business marketing
\end{abstract}

\section{PENDAHULUAN}

Berdasarkan data dari Badan Pusat Statistik (BPS), sektor UMKM menyerap 97\% dari total tenaga kerja di Indonesia dan memberikan kontribusi terhadap PDB sebesar 59\% dan investasi sebesar 55\% dan hingga tahun 2012 di Indonesia terdapat usaha mikro sebanyak kurang lebih 55,85 juta unit usaha yang menyumbang $35,8 \%$ PDB, usaha kecil sebanyak kurang lebih 629,418 unit usaha dan meyumbang $9,7 \%$ PDB, usaha menengah sebanyak kurang lebih 48,997 unit usaha dan menyumbang $13,5 \%$. Dengan jumlah tersebut maka usaha di Indonesia terdiri dari 99,99\% UMKM dan hanya $0,01 \%$ usaha yang berkategori usaha besar.

Dari data tersebut, terbukti bahwa UMKM juga memilki peran penting dalam membangun pondasi ekonomi Indonesia. Pada beberapa kondisi perekonomian dunia yang beberapa tahun mengalami krisis ekonomi dunia, perekonomian Indonesia berada di kondisi stabil karena diuntungkan peran UMKM yang merupakan sektor usaha yang tangguh dan fleksibel dalam menghadapi dinamika ekonomi.
Menurut Partomo, (2009) ada beberapa keunggulan yang dimiliki oleh UMKM jika dibandingkan dengan badan usaha lainnya diantaranya:

1. Inovasi dalam teknologi yang telah dengan mudah terjadi dalam pengembangan produk.

2. Hubungan kemanusiaan yang akrab didalam perusahaan kecil.

3. Kemampuan menciptakan kesempatan kerja cukup banyak atau penyerapannya terhadap tenaga kerja.

4. Fleksibilitas dan kemampuan menyesuaikan diri terhadap kondisi pasar yang berubah dengan cepat dibanding dengan perusahaan skala besar yang pada umumnya birokratis.

5. Terdapatnya dinamisme managerial dan peranan kewirausahaan.

Namun banyak UMKM gagal dalam proses awal pengoperasionalannya, salah satunya alasan gagalnya UMKM tersebut adalah kurangnya pemahaman UMKM terhadap perencanaan pemasaran. perencanaan pemasaran adalah suatu bagan dari suatu desain untuk mencapai suatu tujuan. Tujuannya adalah untuk 
menciptakan nilai bagi konsumen dalam kondisi tetap menguntungkan perusahaan, atau dalam konsep pemasaran saat ini, suatu hubungan yang saling menguntungkan.

Objek yang akan menjadi sasaran dalam pengabdian ini adalah kelompok PKK Asoka Yang berada di Tanjung Piayu komplek perumahan pancur biru lestari 1 RW 05 Kota Batam. Saat ini PKK asoka dipimpin oleh Ibu Anjar wati.

Sebagian besar anggota PKK Asoka bekerja sebagai pedagang, dimana dalam melakukan transaksi sebagian besar masih dilakukan dengan cara tatap muka langsung, dimana konsumen langsung mendatangi tempat penjual untuk membeli produk. Hal tersebut juga menjadi kendala untuk konsumen yang jauh harus membutuhkan waktu, tenaga dan mengeluarkan biaya lebih besar untuk mendapatkan produk yang dibutuhkan, selain itu menjamurnya pedagang juga turut mengancam keberlangsungan usaha anggota PKK asoka. Untuk itu diperlukanlah suatu pembinaan dalam memahami dan membuat perencanaan pemasaran bagi kelompok PKK Asoka Tanjung Piayu, komplek perumahan pancur biru lestari 1 RW 05 Kota Batam

Pendahuluan menguraikan latar belakang permasalahan yang diselesaikan, isu-isu yang terkait dengan masalah yg diselesaikan, ulasan pengabdian yang pernah dilakukan sebelumnya oleh pengabdi lain yg relevan dengan pengabdian yang dilakukan.[1]-[5].

\section{METODE}

\subsection{Waktu dan tempat pelaksanaan}

Pelaksanaan kegiatan Pembinaan bagi Anggota PKK Asoka di kota Batam akan dilaksanakan secara bertahap selama dua kali pertemuan yang dijabarkan pada tabel berikut:

Tabel 2.1 Pelaksanaan kegiatan

\begin{tabular}{|c|c|l|l|}
\hline NO & Waktu & \multicolumn{1}{|c|}{ Kegiatan } & \multicolumn{1}{c|}{$\begin{array}{c}\text { Tim } \\
\text { Dosen }\end{array}$} \\
\hline 1 & $\begin{array}{l}13.00- \\
13.15\end{array}$ & $\begin{array}{l}\text { Pembukaan } \\
\text { dan kata } \\
\text { sambuatan dari } \\
\text { Pengabdi }\end{array}$ & Pengabdi \\
\hline & $\begin{array}{l}13.15- \\
13.30\end{array}$ & $\begin{array}{l}\text { Sambutan dari } \\
\text { Ketua PKK } \\
\text { Asoka }\end{array}$ & $\begin{array}{l}\text { Anjar } \\
\text { Wati }\end{array}$ \\
\hline 3 & & $\begin{array}{l}\text { Acara Inti: } \\
\text { Memberikan } \\
\text { pemahaman } \\
\text { materi tentang } \\
\text { Perencanaan } \\
\text { Pemasaran }\end{array}$ & pengabdi \\
\hline 4 & $16.30-$ & Penutup & Pengabdi \\
\hline
\end{tabular}

\subsection{Metode Yang Ditawarkan}

Untuk memperoleh manfaat dari pengabdian ini serta dapat diimplementasikan, maka metode yang ditawarkan dalam pengabdian ini adalah sebagai berikut:

1. Langkah 1 (Metode ceramah)

Tim Dosen memberikan ceramah dan pemaparan tentang teori Perencanaan Pemasaran

2. Langkah 2 (Metode Tutorial)

Peserta akan diberi Pembinaan dalam membuat Perencanaan Pemasaran mulai dari biaya investasi sampai dengan analisis sosial ekonomi

3. Langkah 3 (Metode diskusi)

Peserta akan diberikan kesempatan untuk mendiskusikan permasalahan yang dihadapi dalam pembuatan Perencanaan Pemasaran.

\section{HASIL DAN PEMBAHASAN}

\subsection{Hasil Pengabdian}

Berdasarkan pembinaan yang telah dilakukan bagi Anggota PKK Asoka di kota Batam diharapakan dapat memberikan dampak yang positif kepada para peserta itu sendiri dan juga kepada tim dosen yang melakukan pembinaan, atau secara rinci hasil yang ingin dicapai dari pelaksanaan 
pembinaan yaitu Berdasarkan hasil Pembinaan kepada Anggota PKK Asoka, saya bersama Tim telah melakukan beberapa hal yang mana dari hasil pembinaan tersebut anggota Anggota PKK Asoka dapat membuat perencanaan pemasaran sendiri. secara garis besar hasil pembinaan ini dapat dijelaskan sebagai berikut, Pelaksanaan pembinaan yang dilaksanakan 2 kali pertemuan dimana materi yang disampaikan adalah menyampaikan mengenai gambaran umum perencanaan pemasaran, materi ini membahas tentang pengenalan mengenai perencanaan pemasaran, pemateri menyampaikan pentingnya perencanaan pemasaran bagi usaha kecil. Peserta pada saat itu belum mengerti mengenai perencanaan pemasaran dan fungsi perencanaan pemasaran. Hingga dilanjutkan pada pertemuan terakhir mengenai pembuatan laporan perencanaan pemasaran, setelah itu barulah peserta mulai memiliki bayangan dan gambaran terhadap apa itu perencanaan pemasaran dan tata cara menyusunnya. Pemberian pembinaan ini juga meliputi membina kemampuan para perserta secara bertahap dalam membuat laporan perencanaan pemasaran, sehingga para peserta tahu dan memahami bentuk dari laporan perencanaan pemasaran.

Adapun Kegiatan pembinaan perencanaan pemasaran bagi Anggota PKK Asoka dilaksanakan selama dua tahap dalam dua kali pertemuan. Adapun susunan acara pembinaan sebagai berikut:

Tabel 4.1 Pelaksanaan kegiatan

\begin{tabular}{|c|c|c|c|}
\hline NO & Waktu & Kegiatan & $\begin{array}{c}\text { Tim } \\
\text { Pengabdi }\end{array}$ \\
\hline 1 & $\begin{array}{l}13.00- \\
13.15\end{array}$ & $\begin{array}{l}\text { Pembukaan } \\
\text { dan kata } \\
\text { sambuatan } \\
\text { dari Pengabdi }\end{array}$ & Pengabdi \\
\hline & $\begin{array}{l}13.15- \\
13.30\end{array}$ & $\begin{array}{l}\text { Sambutan dari } \\
\text { Peserta } \\
\text { pembinaan } \\
\text { perencanaan } \\
\text { pemasaran }\end{array}$ & $\begin{array}{l}\text { Ibu Anjar } \\
\text { Wati }\end{array}$ \\
\hline
\end{tabular}

\begin{tabular}{|c|l|l|l|}
\hline 3 & & $\begin{array}{l}\text { Acara Inti: } \\
\text { Memberikan } \\
\text { pemahaman } \\
\text { materi tentang } \\
\text { Cara } \\
\text { menyusun } \\
\text { perencanaan } \\
\end{array}$ & \\
& & Pengabdi \\
& & \\
\hline 4 & $\begin{array}{l}16.30- \\
16.45\end{array}$ & Penasaran & \\
\hline
\end{tabular}

\section{KESIMPULAN}

Berikut adalah beberapa kesimpulan yang dapat diambil berdasarkan kegiatan pengabdian (Pembinaan) yang telah dilakukan, diantara adalah sebagai berikut:

1. Peserta memiliki pemahaman tentang pembuatan perencanaan pemasaran.

2. Peserta juga telah dapat memahami mengenai ruang lingkup dari perencanaan pemasaran

3. Peserta telah dapat membuat perencanaan pemasaran

\section{SARAN}

Berikut adalah beberapa saran yang dianggap perlu berdasarkan kegiatan pengabdian yang telah dilakukan sebagai berikut:

1. Sebaiknya penyuluhan dan diskusi seperti ini dilaksanakan secara berkala.

2. Sebaiknya semua peserta sudah hadir tepat waktu (sebelum acara dimulai) jadi tidak ada peserta yang datang diawal, ditengah atau bahkan diakhir acara sehingga materi yang disampaikan tidak diulang-ulang.

4. Kedepan jumlah Peserta yang mengikuti Pembinaan perencanaan pemasaran

5. bisa meningkat sehingga dengan adanya pelatihan ini diharapkan dapat membantu UMKM dalam menangani berbagai permasalahan Khusunya yang berkaitan dengan pembuatan perencanaan pemasaran.

\section{UCAPAN TERIMA KASIH}


Penulis mengucapkan terima kasih kepada Universitas Putera Batam melalui LPPM Universitas Putera batam yang telah memberi dukungan financial terhadap pengabdian ini.

\section{DAFTAR PUSTAKA}

BPS. (2014). Batam dalam Angka. Batam: BPS.

Partomo, T.S. (2004). Usaha kecil dan menengah dan koperasi.Working paper series No.9.center for industry and SMEs Studies. Faculty of economics. University of Trisakti 